\title{
Strategi Pemecahan Masalah Pelayanan Pastoral Kontekstual Berdasarkan Yohanes 4:1-26 dan Pemuridan Masa Kini
}

\author{
${ }^{1}$ Sabda Budiman, ${ }^{2}$ Harming \\ ${ }^{1,2}$ Sekolah Tinggi Teologi Simpson Ungaran \\ 1'sabdashow99@gmail.com, ${ }^{2}$ harming984@gmail.com
}

\begin{abstract}
This article describes problem solving strategies in pastoral ministry. The problem solving strategy is certainly carried out with a contextual approach. It means that the principles of pastoral service are aligned with local situations and conditions. This article describes problem solving strategies based on John 4:1-26, by looking at Jesus' example in solving problems experienced by Samaritan women. Furthermore, this article also describes the followup service that can be done to the counselor when it is served. The purpose is of course for the counselor to draw closer and to know Christ more deeply and for the counselor to continue to grow. The method used in this study is a qualitative method with a descriptive approach.
\end{abstract}

Keywords: Jesus; Samaritan woman; pastoral ministry; counselors

Abstrak: Artikel ini menjelaskan tentang strategi pemecahan masalah dalam pelayanan pastoral. Strategi pemecahan masalah tersebut tentunya dilakukan dengan pendekatan kontekstual. Artinya bahwa prinsip-prinsip pelayanan pastoral itu diselaraskan dengan situasi dan kondisi setempat. Artikel ini memaparkan strategi pemecahan masalah berdasarkan Yohanes 4:1-26, dengan melihat teladan Yesus dalam memecahkan masalah yang dialami oleh perempuan Samaria. Lebih jauh, artikel ini juga menjelaskan tentang pelayanan follow up yang dapat dilakukan kepada konseli ketika sudah dilayani. Tujuannya tentu agar konseli semakin dekat dan mengenal Kristus lebih dalam lagi serta agar konseli terus bertumbuh. Metode yang digunakan dalam penelitian ini ialah metode kualitatif dengan pendekatan deskriptif.

Kata kunci: Yesus; perempuan Samaria; pelayanan pastoral; konseli

\section{Pendahuluan}

Pastoral merupakan pelayanan yang dilakukan antara manusia satu dengan manusia lainnya dengan pelayanan berpusat pada iman Kristen. Abineno mengatakan bahwa tugas yang sesungguhnya dari pastoral ialah untuk memelihara manusia yang adalah roh. Abineno juga menegaskan bahwa pastoral merupakan pelayanan yang memperhatikan harapan dan kekecewaan, keberanian dan ketakutan, kepercayaan dan 
kebimbingan, dan sebagainya dari pihak yang dilayani, tentunya dengan perspektif Kerajaan Allah. ${ }^{1}$

Pelayanan pastoral merupakan pelayanan yang dapat dilakukan oleh semua orang percaya. Pelayanan pastoral umumnya dipahami sebagai tugas gembala sidang ataupun pendeta. Namun sesungguhnya pemahaman tersebut kurang tepat. Pelayanan pastoral merupakan tugas dan tanggung jawab semua orang percaya. Kapanpun dan dimanapun, orang percaya seyogiyanya siap sedia untuk melakukan pelayanan pastoral.

Dalam pelaksanaannya, pelayanan pastoral tentu akan selalu menemukan masalah. Masalah yang ditemukan pun beragam, mulai dari masalah keluarga, pergaulan, karakter, dan pergumulan pribadi lainnya. Sebagaimana yang dikatakan oleh Intarti bahwa masalah yang dialami oleh manusia disebabkan oleh berbagai hal, mulai dari perbedaan cara berpikir, suku, agama, sosial dan lain sebagainya. Hal tersebut dapat menyebabkan tekanan dalam diri orang. ${ }^{2}$ Selain itu, Selvianti juga menegaskan bahwa masalah yang dialami seseorang memberikan pengaruh yang besar pada pola pikir dan perilakunya. ${ }^{3}$ Hal tersebut menunjukkan bahwa masalah yang dialami memiliki dampak yang besar bagi kehidupan seseorang secara psikologis maupun perilaku.

Melihat keadaan zaman dan kebutuhan serta pola pikir manusia yang bersifat dinamis, perlu dilakukan pelayanan pastoral bersifat kontekstual. Kontekstual ialah situasi yang berhubungan atau berkaitan dengan suatu peristiwa maupun kejadian. ${ }^{4}$ Sebagaimana yang dipahami oleh banyak teolog pastoral Indonesia dalam berteologi tentang pastoral bahwa teologi pastoral bukanlah suatu teologi dari pelayanan pastoral, melainkan teologi yang kontekstual. ${ }^{5}$ Selain itu, Herfest mengatakan bahwa pelayanan pastoral menolong seseorang untuk menyadari hubungannya dengan Allah dan sesama di dalam situasi tertentu. ${ }^{6}$ Hal tersebut salah satunya tentu dilatarbelakangi oleh keberagaman manusia Indonesia. Pelayanan pastoral kontekstual tentunya juga tidak terlepas dari prinsip-prinsip Alkitab

Alkitab sebagai sumber dan dasar dari pelayanan pastoral, menyediakan banyak contoh masalah-masalah pastoral dan cara mengatasinya, secara khusus dalam Perjanjian Baru. Yesus merupakan tokoh sempurna dalam pelayanan pastoral. Ia disebut sebagai Gembala yang baik (Yoh. 10:11,14) dan Gembala Agung (Ibr. 13:20; 1 Pet. 5:4). Yesus memberikan contoh konkret dalam mengatasi masalah pelayanan pastoral. Ranto mengatakan bahwa Injil Yohanes merupakan kitab Injil yang memiliki keunikan dalam sudut pandang pastoral, yaitu tentang pendeskripsian Yesus dengan pribadi dan

\footnotetext{
${ }^{1}$ Johannes Ludwig Chrysostomus Abineno, Pedoman Praktis Untuk Pelayanan Pastoral (BPK Gunung Mulia, 2010), 16.

${ }^{2}$ Esther Rela Intarti, "Peranan Firman Allah Dalam Pelayanan Konseling Pastoral Yang Holistik," Regula Fidei 3, no. 2 (2018): 95.

${ }^{3}$ Selvianti, "Menerapkan Prinsip Pelayanan Konseling Berdasarkan Injil Yohanes," Jurnal Teologi dan Pendidikan Kristen Kontekstual 1, no. 2 (December 2018): 254.

${ }^{4}$ Abdul Kadir, "Konsep Pembelajaran Konseptual Di Sekolah," Dinamika Ilmu 13, no. 1 (June 2013): 25.

${ }^{5}$ Mesach Krisetya, Bela Rasa Yang Dibagirasakan (Jakarta: Duta Ministri, 2015), 50.

${ }^{6}$ Nehemia Mimery, Rahasia Tentang Penggembalaan (Jakarta: Mimery Press, n.d.), 6.
} 
karya-Nya. Keunikan tersebut juga terlihat dari pendekatan Yesus di dalam pelayananNya. ${ }^{7}$ Salah satu contohnya ialah ketika Yesus melayani perempuan Samaria (Yoh. 4:126). Dalam pelayanan Yesus kepada perempuan Samaria tersebut, Yesus menggunakan pendekatan yang unik, yang sekarang dikenal dengan pendekatan kontekstual. Pola pelayanan Yesus ini dapat digunakan dalam pelayanan pastoral bernuansa kontekstual saat ini.

Setelah seorang pelayan Tuhan maupun orang percaya melakukan pelayanan untuk menolong orang lain mengatasi masalahnya, perlu adanya follow up dalam hal pemuridan bagi orang tersebut. Tujuannya ialah agar konseli (orang yang dilayani) dapat bertumbuh, berakar, dan menghasilkan buah. Dalam artikelnya, Purba mengatakan bahwa salah satu tujuan utama pemuridan adalah untuk memperkenalkan Yesus sebagai Tuhan dan Juruselamat. ${ }^{8}$ Hal senada juga yang diungkapkan oleh Scoot bahwa fungsi pemuridan salah satunya ialah untuk memperlengkapi setiap individu agar bertumbuh di dalam Kristus. ${ }^{9}$ Lebih luas Hudson menjelaskan bahwa pemuridan bertujuan untuk memampukan seseorang menghidupi hidupnya dengan mencerminkan maksud Tuhan bagi kehidupan di sekitar. ${ }^{10}$ Terlihat jelas dari berbagai pendapat tersebut bahwa pemuridan berfokus pada pertumbuhan dalam Kristus dan berpusat pada firman Tuhan.

Berdasarkan penjelasan di atas, didapati bahwa pentingnya mengkaji strategi pelayanan pastoral yang dibangun melalui strategi yang ada dalam Alkitab. Selain itu, pelayanan pastoral yang relevan ialah pelayanan pastoral yang bersifat kontekstual. Artinya bahwa seorang pelayan perlu memosisikan diri dalam situasi, suasana, perasaan, dan pemahaman dengan konseli, namun tidak terpengaruh oleh kondisi. Nilai-nilai alkitabiah tetap dipertahankan. Pelayanan Yesus kepada perempuan Samaria dalam Yohanes 4:1-26 merupakan contoh pelayanan kontekstual yang dapat diterapkan dalam pelayanan pastoral saat ini. Dalam cerita tersebut juga Yesus memberikan pengajaran kepada perempuan Samaria itu. Hal itu menunjukkan bahwa perlunya melakukan follow up kepada orang yang telah dilayani. Penelitian ini lebih berfokus kepada pemecahan masalah pastoral kontekstual kepada pribadi seseorang (personal) dengan mengesampingkan pemecahan masalah mengenai pengorganisasian, sistem gereja dan sejenisnya.

Setelah mengamati latar belakang dan proposisi di atas, peneliti merumuskan masalah penelitian sebagai berikut: 1) Apa saja strategi pemecahan masalah pelayanan kontekstual berdasarkan Yohanes 4:1-26; 2) Bagaiamana melakukan follow up dalam pemuridan kepada orang yang telah dilayani? Penelitian ini bertujuan untuk

\footnotetext{
${ }^{7}$ Ranto, "Pendekatan Pastoral Yesus Dalam Yohanes 21:15-19 Dan Aplikasinya Dalam Pelayanan Pastoral Pemulihan,” Rhema: Jurnal Teologi Biblika dan Praktik 4, no. 2 (2018): 87.

${ }^{8}$ Asmat Purba, "Pemuridan Sebagai Tugas Dosen Pendidikan Agama Kristen Di Perguruan Tinggi," TEDC 8, no. 1 (January 2014): 70.

${ }^{9}$ Morton Scoot, Pemuridan untuk Semua Orang (Surakarta: Literatur Perkantas, 2011).

${ }^{10}$ Neil Hudson, Imagine Church: Gereja Idaman, Gereja Pemuridan (Jawa Timur: Literatur Perkantas, 2017), 37.
} 
memaparkan strategi pemecahan masalah pelayanan kontekstual berdasarkan Yohanes 4:1-26 dan follow up yang dilakukan untuk memuridkan.

\section{Metode Penelitian}

Dalam penelitian ini, peneliti mengunakan metode penelitian kualitatif dengan pendekatan deskriptif. Moleong menjelaskan bahwa data yang dikumpulkan dalam pendekatan deskriptif berkemungkinan menjadi kunci terhadap apa yang telah diteliti. Selain itu, dalam pendekatan deskriptif, peneliti tidak akan memandang bahwa hal-hal yang diamati itu memang demikian adanya. ${ }^{11}$ Adapun proses penelitian yang dilakukan oleh peneliti ialah mengamati pentingnya pembahasan topik dalam penelitian ini dibahas dengan mengamati fakta empiris. Kemudian melakukan identifikasi masalah. Setelah itu, peneliti mengumpulkan data yang berkaitan dengan topik dan mengkaji serta menyajikan hasil pengkajian tersebut dengan sistematis.

\section{Hasil dan Pembahasan}

\section{Strategi Pemecahan Masalah Secara Kontekstual Berdasarkan Yohanes 4:1-26}

Kesatu, Memahami Sosial-Budaya. Dalam konteks masa dan situasi saat itu, orang Samaria tidak bergaul dengan orang Yahudi. Orang Yahudi menganggap orang Samaria merupakan orang kafir karena melakukan praktik kawin campur sehingga keturunan yang dihasilkan menjadi tidak murni lagi sebagai orang Yahudi. Baik dalam darah maupun agama, orang Samaria merupakan Yahudi campuran, keturunan orangorang dari daerah-daerah kekuasaan lain yang ditempatkan di Samaria oleh raja Asyur setelah penawanan sepuluh suku. ${ }^{12}$ Kehidupan budaya Yahudi dan Samaria saat itu berbeda sama sekali.

Selain budaya, perlu dilihat juga kehidupan sosial dan kebiasaan orang-orang pada masa itu, kapan perempuan-perempuan biasanya mengambil air. Dalam Tafsiran Alkitab Wycliffe mengungkapkan bahwa perjalanan diam-diam oleh perempuan Samaria itu ke sumur Yakub setiap hari menunjukkan adanya pemboikotan kepada perempuan Samaria itu yang dilakukan oleh para perempuan lain dalam masyarakat tersebut. ${ }^{13}$ Hal tersebut juga ditegaskan Tafsiran Alkitab Abad ke-21 bahwa tidak biasa bagi seorang perempuan untuk pergi sendirian. Perempuan Samaria itu barangkali dianggap sebagai seorang yang terbuang dalam masyarakat. ${ }^{14}$ Hal itu menunjukkan bahwa kehidupan sosial perempuan Samaria tersebut tidaklah seperti kehidupan sosial perempuan-perempuan lain pada masa itu.

\footnotetext{
${ }^{11}$ Lexy J. Moleong, Metodologi Penelitian Kualitatif (Bandung: Remaja Rosdakarya, 2018), 11.

${ }^{12}$ Matthew Henry, Tafsiran Matthew Henry: Matius (Surabaya: Momentum, 2007), 3016.

${ }^{13}$ Charles F. Pfeiffer and Everett F. Harrison, eds., Tafsiran Alkitab Wycliffe Volume 3 (Malang: Gandum Mas, n.d.), 3019.

${ }^{14}$ D.A. Carson et al., Tafsiran Alkitab Abad Ke-21 Jilid 3: Matius-Wahyu (Jakarta: Yayasan Komunikasi Bina Kasih, 2017), 213.
} 
Dalam melakukan pelayanan pastoral untuk memecahkan masalah yang dialami seseorang, perlu dilakukan secara kontekstual dengan memahami konteks sosial-budaya dengan benar agar tidak menimbulkan persepsi yang keliru. Tuhan Yesus telah memberikan contoh yang baik dalam memahami sosial-budaya perempuan Samaria, sehingga secara manusia (dengan mengesampingkan sifat ke-Tuhanan yang Mahatahu) Yesus tidak memiliki persepsi yang “jahat” terhadap perempuan Samaria.

Kedua, Memahami Kebutuhan. Setiap diri manusia terdapat sejumlah kebutuhan asasi. Memahami dan mengerti kebutuhan dalam diri setiap individu akan membantu manusia lain mengerti apa yang dibutuhkan oleh individu tersebut. Menurut Abraham Maslow terdapat lima kebutuhan manusia yaitu kebutuhan fisiologi (physiological needs) seperti udara, air, seks, makanan, pakaian, kebutuhan rasa aman (safety needs), kebutuhan mencintai dan dicintai (love and belonging needs), kebutuhan akan harga diri (esteem needs), dan kebutuhan aktualisasi diri (self-actualization needs). Kebutuhankebutuhan asasi tersebut kemudian dikenal saat ini dengan teori hierarchy of needs. ${ }^{15}$ Kemudian menurut Brill, ada dua kebutuhan pokok manusia yaitu kebutuhan jasmani yang meliputi makanan, pakaian, istirahat, olahraga, sosial, keuangan, dan kebutuhan rohani yang meliputi kejiwaan atau batin seperti kasih saying dan spiritual, yaitu hubungan pribadi dengan Sang Pencipta. ${ }^{16}$ Kebutuhan-kebutuhan yang dipaparkan tersebut pasti dimiliki oleh setiap manusia.

Demikian pula perempuan Samaria memiliki kebutuhan-kebutuhan mendasar. Yesus memahami bahwa perempuan Samaria tersebut membutuhkan air. Air merupakan satu bagian penting dalam hidup manusia. Setiap manusia akan melakukan sesuatu untuk memenuhi kebutuhan hidupnya. Jika ada peluang atau penawaran dari pihak lain untuk memenuhi kebutuhan hidup orang seseorang, ia tentu tidak akan menolaknya. Itulah yang Yesus lakukan kepada perempuan Samaria. Yesus mengetahui kebutuhan perempuan Samaria. Oleh karena itu, Ia menawarkan kepada perempuan Samaria "air" yang membuat perempuan Samaria tidak akan haus untuk selama-lamanya (Yoh. 4:14). Perempuan Samaria itu tentu tertarik oleh apa yang Yesus tawarkan. Dalam buku Tafsiran Matthew Henry menjelaskan bahwa seorang perempuan datang untuk menimba mengisyaratkan bahwa perempuan tersebut miskin dan tidak memiliki seorang hamba untuk menimba air baginya. ${ }^{17}$ Diperkirakan bahwa selain seorang yang diisolir dalam masyarakat, perempuan Samaria tersebut juga seorang yang miskin. Hal itu semakin menegaskan bahwa betapa pentingnya kebutuhan air bagi perempuan Samaria tersebut. Ditambah tawaran dari Yesus bahwa air yang Ia berikan membuat perempuan Samaria tersebut tidak akan haus untuk selama-lamanya (Yohanes 4:14), membuat perempuan

\footnotetext{
${ }^{15}$ Rahmat H. Deden and Zaenudin A. Naufel, Teori Dan Aplikasi Psikologi Kepribadian Dalam Konseling (Bogor: Ghalia Indonesia, 2011), 165-166.

${ }^{16}$ J. Wesley Brill, Dasar Yang Teguh (Bandung: Kalam Hidup, 2015), 238.

${ }^{17}$ Henry, Tafsiran Matthew Henry: Matius, 3016.
} 
Samaria itu semakin tertarik. Ia mengharapkan air tersebut agar ia tidak datang untuk menimba air ke sumur itu lagi.

Selain itu, perempuan Samaria ini ialah seorang yang mengalami penolakan sehingga membuatnya dijauhi, malu, menarik diri dari pergaulan. ${ }^{18}$ Keadaan tersebut kemudian membuatnya membutuhkan kasih sayang, dihargai, dan juga rasa aman. Dari dialog Yesus dengan perempuan Samaria itu juga terlihat nyata bahwa kebutuhan rohani dan moral perempuan itu sangat besar. ${ }^{19}$ Dalam hal ini pun Yesus memenuhi apa yang perempuan Samaria butuhkan baik kebutuhan rohani maupun moral. Yesus tidak menghakimi (rasa aman), Yesus memberikan perhatian (kasih sayang), dan Yesus juga tidak menuduh dan tidak memojokkan serta meluangkan waktu untuk berdialog dengan perempuan Samaria (harga diri). Selain itu, kebutuhan yang mendasar dan juga kebutuhan dari semua kebutuhan yang dipaparkan oleh Abraham Maslow dan Brill di bagian sebelumnya, tercakup dalam kebutuhan akan keselamatan jiwa. Yesus memahami kebutuhan yang paling mendasar dari perempuan Samaria itu, yaitu keselamatan jiwa, yang mana kebutuhan akan keselamatan tersebut secara tidak langsung berkaitan dengan kebutuhan-kebutuhan lainnya. Melalui teladan Yesus, memahami kebutuhan sangat penting guna memecahkan masalah yang dihadapi dalam pelayanan pastoral kontekstual.

Ketiga, Memahami Masalah. Tahap yang penting dalam pemecahan masalah lainnya ialah memahami masalah. Masalah dapat ditemukan melalui sikap konseli yang berlawanan dengan kehidupan sosial-budaya yang ada. Memahami masalah yang dialami oleh konseli merupakan hal penting karena hal itu merupakan jembatan untuk melanjutkan pada tahap pemecahan masalah. Masalah juga dapat ditemukan melalui percakapan yang dilakukan oleh seorang pelayan dengan konseli. Dalam hal ini, seorang pelayan perlu memberikan arahan dengan pertanyaan ataupun pernyataan untuk menemukan dasar dari masalah yang dialami oleh konseli. Yesus mengajukan suatu pernyataan dan pertanyaan kepada perempuan Samaria untuk "memancing"nya mengungkapkan masalah yang ia alami.

Perlu juga seorang pelayan untuk mengidentifikasi masalah. Tidak semua masalah yang dialami seseorang dapat digolongkan ke dalam masalah pastoral. Salah satu tugas seorang pelayan ialah untuk merumuskan suatu masalah. ${ }^{20}$ Yesus tentu mengetahui mengapa perempuan Samaria menimba air pada siang hari. Yesus kemudian melihat dan memahami masalah dari perempuan Samaria tersebut hingga masalah mendasarnya, yaitu kebutuhan akan keselamatan jiwa.

Dalam memahami masalah pun tidak dilakukan oleh pihak pelayan saja, tetapi juga orang yang dilayani (istilah untuk orang yang dilayani seterusnya penulis menggunakan istilah konseli) perlu memahami masalah mendasar yang dialaminya. Hal

${ }^{18}$ Titik Haryani, “Pentingnya Pelayanan 'Inner Healing' dalam Gereja,” Jurnal Antusias 5, no. 1 (June 2017): 121.

${ }^{19}$ D.A. Carson et al., Tafsiran Alkitab Abad Ke-21 Jilid 3: Matius-Wahyu, 213.

${ }^{20}$ Susanto, Bahan Kuliah Konseling Pastoral, n.d., 38. 
tersebut juga yang diungkapkan oleh Halawa bahwa konseli juga membutuhkan pertolongan untuk memahami masalahnya. ${ }^{21}$ Dengan memahami masalah mendasar, konseli dapat memutuskan tindakan apa yang akan ia lakukan selanjutnya. Di sinilah peran seorang pelayan. Hal itu juga yang dikatakan Pattinama bahwa seorang pelayan memiliki tugas untuk menolong konseli dengan cara memberikan nasehat dan juga memberikan pengertian kepada konseli berkaitan dengan masalah mendasar yang dialami oleh konseli. Dengan melakukan hal tersebut, konseli dapat memahami masalah yang dialaminya dan dapat mengambil keputusan yang bijaksana untuk menyelesaikan masalah sesuai kebutuhan konseli itu sendiri. ${ }^{22}$ Yesus melakukan hal tersebut kepada perempuan Samaria. Yesus mengajukan pertanyaan yang "tajam" kepada perempuan Samaria tersebut, yaitu pertanyaan yang menyentuh kehidupan pribadi perempuan Samaria tersebut. Pertanyaan itu menuntut adanya kejujuran dan keterbukaan dari perempuan Samaria itu. Pertanyaan tersebut juga membuat perempuan Samaria itu secara tidak langsung sadar akan masalah pribadinya, yaitu kehidupan yang berdosa dan ia membutuhkan jalan keselamatan. Memahami konteks dan masalah mendasar akan menolong untuk mengatasi masalah pastoral.

Keempat, Memahami Cara Pandang. "Berbeda budaya, berbeda cara pandang", kurang lebih seperti itu peribahasa yang dilantunkan terkait pembahasan memahami cara pandang (worldview). Dalam melayani seorang konseli, seorang pelayan sepatutnya memahami cara pandang konseli. Yesus tidak semerta-merta langsung memberikan masukan atau nasihat ketika melayani perempuan Samaria, Yesus terlebih dahulu memahami worldview perempuan Samaria tersebut. Dalam memahamai cara pandang orang yang dilayani juga perlu melihat konteks budaya setempat. Hal itu juga yang diungkapkan oleh Kneller bahwa memahami manusia tidak hanya dari sudut pandang individu itu sendiri, tetapi juga dari konteks budaya. ${ }^{23}$ Budaya secara tidak langsung telah mempengaruhi pola pikir seseorang. Dalam hal ini, perempuan Samaria telah terpengaruh oleh budaya setempat.

Melalui percakapan dengan perempuan Samaria, Yesus kembali menemukan ada konsep atau pemahaman yang keliru dari perempuan Samaria terkait air yang Yesus maksudkan dan penyembahan. Ini juga merupakan salah satu masalah yang perlu dipecahkan. Perempuan Samaria tersebut hanya berpikir secara harafiah tentang air yang Yesus tawarkan. Perempuan itu belum menyadari akan dimensi rohani yang terkandung dalam penawaran Yesus tersebut. Perempuan Samaria itu juga hanya membayangkan akan kebutuhan jasmaninya terpenuhi, sehingga ia tidak lagi kembali ke sumur itu untuk

\footnotetext{
${ }^{21}$ Junius Halawa, "Pastoral Konseling Psikologi Alkitabiah Bagi Perempuan Yang Telah Melakukan Hubungan Seks Sebelum Menikah,” Missio Ecclesiae 7, no. 2 (October 2018): 288.

${ }^{22}$ Yenny Anita Pattinama, "Pastoral Konseling Menurut Yehezkiel 34:16 Sebagai Upaya Pemulihan Mental," Jurnal Scipta Teologi dan Pelaksanaan Kontekstual 3, no. 2 (2018): 175.

${ }^{23}$ G.F. Kneller, Educational Anthropology: An Introduction (New York: John Wiley and Scons, 1965), 99.
} 
menimba air. ${ }^{24}$ Hal tersebut nampak bahwa perempuan Samaria itu tidak memahami akan kebutuhannya sendiri. Mengenai penyembahan juga terjadi cara pandang yang salah dari perempuan Samaria. Perempuan Samaria memiliki pandangan bahwa menyembah harus dilakukan di atas gunung (dalam konteks ini adalah Gunung Gerizim). Padahal sebagaimana yang Yesus katakan bahwa manusia harus menyembah Allah dalam roh dan kebenaran dan tidak dibatasi oleh tempat-tempat tertentu. Yesus menangkap dan memahami cara pandang perempuan Samaria tersebut sehingga Yesus dengan mudah melayani perempuan itu.

Penjelasan di atas menunjukkan bahwa penting bagi seorang pelayan untuk memahami cara pandang konseli. Cara pandang yang salah terhadap masalah atau yang berkaitan dengan masalah tersebut akan membuat konseli sulit keluar dari masalahnya. Begitu pun dari pihak yang melayani, tanpa memahami cara pandang konseli sulit bagi seorang pelayan untuk menemukan jalan keluar dan membantu konseli mengatasi masalahnya.

Kelima, Membuka Wawasan. Seorang pelayan, dalam melayani konseli, tidak memberikan keputusan untuk diambil oleh konseli, tetapi hanya mengarahkan dan membuka wawasan konseli. Keputusan atau tindakan selanjutnya itu diputuskan oleh konseli itu sendiri. Susabda mengatakan bahwa seorang pelayan Tuhan yang melayani konseli bertanggung jawab untuk menolong konseli agar dapat memahami masalahnya. Pelayan Tuhan juga bertugas untuk memberikan masukan dan saran terkait masalahnya agar konseli mampu melihat tujuan hidupnya dan mencoba mencapai tujuan itu dengan takaran, kekuatan, dan kemampuan sebagaimana kemampuan yang Tuhan berikan kepadanya. ${ }^{25}$ Selain itu, dalam hal membuka wawasan konseli juga bertujuan untuk menyadarkan konseli akan keselarasan hubungan akan tujuan hidupnya dengan apa yang Tuhan kehendaki. ${ }^{26}$ Karena itu, pelayanan pastoral yang baik ialah pelayanan yang memberikan ruang untuk konseli mengambil keputusan sesuai dengan kebutuhan dan kemampuannya.

Dalam konteks Yohanes 4:1-26, tidak ada indikasi bahwa Yesus memaksa perempuan Samaria itu untuk percaya kepada-Nya dan apa yang ia katakan. Yesus hanya menjelaskan tentang "air" bersifat rohani (Yoh. 4:13-14). Wycliffe menjelaskan bahwa "air hidup" yang Yesus maksudkan ialah diri-Nya sendiri. ${ }^{27}$ Kemudian Yesus juga menjelaskan tentang penyembahan yang benar (Yoh. 4:21-24). Konsep yang keliru dari perempuan Samaria tadinya, kini pemikirannya telah dibukakan oleh Yesus. Di dalam cerita ini jelas menunjukkan bahwa Yesus melakukan pelayanan tersebut hanya untuk memberikan pilihan kepada perempuan Samaria itu. Keputusan akhir dari kisah ini tidak terletak pada Yesus selaku pelayan, tetapi keputusan terletak pada pribadi

\footnotetext{
${ }^{24}$ D.A. Carson et al., Tafsiran Alkitab Abad Ke-21 Jilid 3: Matius-Wahyu, 213.

${ }^{25}$ Yakub B. Susabda, Pastoral Konseling Jilid 1 (Malang: Gandum Mas, 2003), 4.

${ }^{26}$ Florentina Sianipar, "Strategi Pelayanan Pastoral Konseling Sebagai Upaya Meningkatkan Antusiasme Jemaat Dalam Beribadah,” Missio Ecclesiae 8, no. 2 (October 2019): 142.

${ }^{27}$ Pfeiffer and Harrison, Tafsiran Alkitab Wycliffe Volume 3, 3019.
} 
perempuan Samaria itu yang mana ia memutuskan untuk percaya kepada Yesus dan tidak sebatas itu, ia juga memberitakan kepada orang lain bahwa Yesus adalah Mesias.

\section{Pemuridan pada Masa Kini}

Setelah melakukan pemecahan masalah dalam pelayanan pastoral, perlu adanya tindak lanjut terhadap orang atau kelompok yang dilayani. Hal itu dilakukan agar orang atau kelompok yang dilayani tersebut dapat bertumbuh dan sebagai bukti tanggung jawab pelayan Tuhan terhadap domba-domba yang dilayaninya.

Pemuridan yang dimaksud, antara lain: Kesatu, Melalui Kelompok Sel. Tanto menjelaskan bahwa kelompok sel ialah suatu kelompok kecil yang bersepakat untuk bertemu di setiap minggu secara rutin untuk membangun anggota tubuh Kristus. Sasaran dari kelompok sel ini ialah bermultiplikasi. ${ }^{28}$ Wagner menjelaskan bahwa kelompok sel ialah Eight or twelve believers gathered to minister to each other, to grow in their sensed loved and unity, and to encourage one another to full commitment to Christ. ${ }^{, 29}$ Budiman dan Susanto mengunkapkan bahwa kelompok sel ialah sekelompok orang yang di dalamnya terdiri dari 4 hingga 12 orang yang di dalamnya terdapat suatu persekutuan dan juga pembinaan agar kemudian setiap individu dapat bermultiplikasi dan berlipat ganda. ${ }^{30}$ Dapat dipahami bahwa kelompok sel ialah suatu kumpulan kecil yang terbatas yang di dalamnya dapat dengan leluasa berdiskusi dan sharing guna bertumbuh bersama dalam Kristus agar dapat membina orang lain dan menjangkau orang-orang di luar Kristus.

Dalam Alkitab, Yesus menggunakan pola kelompok sel dalam memuridkan, yaitu dengan membentuk komunitas kecil yang terdiri dari 13 orang termasuk Yesus. Selain itu, dalam Gereja mula-mula juga terlihat pola kelompok sel. Dalam Kisah Para Rasul 2:46-47 mengisahkan bahwa gereja mula-mula berkumpul di rumah-rumah secara bergiliran. Kedua contoh ini memberikan gambaran mengenai pola kelompok kecil atau kelompok sel. ${ }^{31}$ Melalui gambaran-gambaran pelayanan berpola kelompok kecil dalam Alkitab, seperti yang dipaparkan sekilas tersebut, pola pelayanan kelompok sel telah berkembang dan tertata dengan cukup baik. Contoh pertumbuhan gereja di Korea Selatan sebagian besar dikarenakan oleh pelayanan berpola kelompok sel. ${ }^{32}$ Comiskey gereja-gereja dapat menggunakan pola kelompok sel sebagai ujung tombak pelayanannya. ${ }^{33}$ Pelayanan kelompok sel dapat dapat digunakan sebagai sarana untuk memberikan pertumbuhan iman kepada konseli.

\footnotetext{
${ }^{28}$ Obaja Tanto, 12 Prinsip Kelompok Sel (Solo: Departemen Media, 2000), 25.

${ }^{29}$ Peter Wagner, Your Church Can Grow (Venture: Regal Books, 1984), 124.

${ }^{30}$ Sabda Budiman and Susanto Susanto, "Strategi Pelayanan Pastoral di Masa Pandemi Covid-19 Menuju Pertumbuhan Gereja yang Sehat," PNEUMATIKOS: Jurnal Teologi Kependetaan 11, no. 2 (April 5, 2021): 97.

${ }^{31}$ Amos Hosea, "FENOMENA KELOMPOK SEL (CELL GROUP) DALAM GEREJA LOKAL," Diegesis : Jurnal Teologi 4, no. 1 (September 2019): 3.

${ }^{32}$ Sukamnto, Rahasia Keberhasilan Gereja Di Korea (Yogyakarta: ANDI, 2006), 76.

${ }^{33}$ Joel Comiskey, Ledakan Kelompok Sel (Jakarta: Metanoia, 1998), 15.
} 
Kedua, Melalui Komunitas. Komunitas adalah sekelompok orang yang saling peduli satu dengan yang lain melebihi dari pada yang seharusnya, yang mana di dalam komunitas itu terjalin suatu relasi yang sangat erat antar anggota komunitas yang disebabkan adanya kesamaan kepentingan dan nilai-nilai. ${ }^{34}$ Iver juga menegaskan bahwa salah satu yang menjadi dasar keberadaan komunitas ialah sentiment community. Di dalam sentiment community itu terdapa tiga hal, yaitu seperasaan, sepenanggungan, dan saling memerlukan. ${ }^{35}$ Pernyataan-pernyataan tersebut menandakan bahwa komunitas terbentuk dan tetap bertahan salah satu penyebab utamanya ialah kepentingan bersama. Salah satu contoh komunitas ialah komunitas sepak bola. Di dalamnya terdapat orangorang yang memilik latar belakang yang berbeda, namun saling mengisi satu dengan lain sehingga terjalin keakraban dan kenyamanan.

Penjelasan mengenai pentingnya komunitas dalam hidup manusia telah menciptakan peluang bagi gereja dalam memuridkan jemaat. Upaya tindak lanjut bagi orang atau jemaat yang telah dilayani dapat dilakukan melalui komunitas. Pelayanan komunitas hampir mirip dengan kelompok sel, namun juga terdapat perbedaan yang mencolok dalam pelaksanaannya. Kelompok sel merupakan perkumpulan yang berfokus kepada hal-hal yang bersifat rohani seperti berdoa, belajar firman Tuhan bersama, tetapi komunitas merupakan kumpulan umum namun di sela-sela kegiatan komunitas, dapat diisi dengan berita firman yang dibungkus dengan situasi dan kondisi komunitas tersebut.

Ketiga, Melalui Persekutuan Keluarga. Karakter dan nilai-nilai hidup pada umumnya tersebentuk di dalam keluarga. Keluarga dalam bagian ini ialah keluarga inti. Keluarga merupakan unit terkecil di dalam masyarakat. Peran keluarga dalam pembentukan jasmani maupun rohani sangatlah besar. Keluarga yang baik tentu akan menghasilkan anggota keluarga yang baik pula. Melihat kenyataan tersebut, gereja dapat menjadikan itu sebagai peluang untuk melayani dan menjangkau kaum keluarga lainnya. Orang tua Kristen seyogiyanya memiliki pola asuh yang menekankan nilai-nilai kristiani. Dalam lingkungan keluarga, orang tua Kristen membentuk karakter anak dengan mendasarkannya pada aspek spiritual, iman, serta kehidupan kristiani yang praktis sehingga dalam lingkungan keluarga dapat bertumbuh dan berkarakter. ${ }^{36}$ Pernyataan tersebut menegaskan bahwa keluarga berperan besar dalam membentuk karakter dan iman anggota di dalamnya.

Dalam melakukan follow up terhadap konseli agar bertumbuh lebih dewasa, konseli perlu untuk ikut dan terlibat dalam persekutuan keluarga. Saragih menjelaskan bahwa gereja dan sekolah hanya membantu dalam mendidik dan membina seseorang.

\footnotetext{
${ }^{34}$ Mayang R.N. Fauziyah, N.A. Damayani, and A.S. Rohman, "Perilaku Knowledge Sharing Multi Bahasa Pada Komunitas Fakta Bahasa," Jurnal Kajian Informasi dan Perpustakaan 2, no. 2 (December 2014): 91.

${ }^{35}$ Soerjono Soekanto, Sosiologi: Suatu Pengantar (Jakarta: Rajawali Press, 1983), 143.

${ }^{36}$ May Rauli Simamora and Johanes Waldes Hasugian, "Penanaman Nilai-Nilai Kristiani Bagi Ketahanan Keluarga Di Era Disrupsi," REGULA FIDEI: Jurnal Pendidikan Agama Kristen 5, no. 1 (June 2020): 23.
} 
Pengaruh utama terhadap seorang individu ialah di dalam keluarga. ${ }^{37}$ Karena itu, persekutuan keluarga berperan penting dalam memberikan pertumbuhan rohani seseorang. Persekutuan keluarga juga dapat menimbulkan suasana baru bagi keluarga. Namun hal itu bukanlah suatu masalah yang besar dalam pelaksaannya. Selain itu, gereja perlu mendorong kepala keluarganya atau orang yang dapat dipercaya dalam keluarga untuk mengkoordinir persekutuan yang dilakukan. Pemuridan melalui persekutuan keluarga memberikan peluang juga bagi para anggota keluarganya bertumbuh. Persekutuan keluarga membuat konseli merasa lebih dekat dengan keluarganya. Kasih yang mula-mula di dalam keluarga menjadi pulih kembali. ${ }^{38}$

\section{Kesimpulan}

Dalam pemaparan tentang strategi pemecahan masalah pastoral kontekstual berdasarkan Yohanes 4:1-26 memberikan lima tahap atau lima strategi, yaitu memahami sosial-budaya, memahami kebutuhan konseli, memahami masalah yang konseli alami, memahami cara pandang, dan membuka wawasan konseli. Kelima startegi ini dapat dilakukan oleh pelayan Tuhan dalam memecahkan masalah pelayanan pastoral terhadap seseorang. Penjelasan di atas menunjukkan bahwa dalam rangka pemecahan masalah perlu bagi seorang pelayan untuk memahami berbagai aspek agar dapat melayani dengan efektif. Pelayanan pastoral yang dilakukan kepada seseorang perlu ditindaklanjuti agar orang yang dilayani tersebut semakin bertumbuh dalam pengenalan yang benar tentang Allah dalam Kristus. Nampak bahwa pelayanan pastoral kontekstual tidak hanya bertujuan untuk menolong konseli menemukan dan mengatasi masalahnya, tetapi juga menolong konseli untuk bertumbuh dan berbuah dan juga membuat konseli tersebut sampai pada tahap ia dapat melayani orang yang mengalami masalah.

\section{Referensi}

Abineno, Johannes Ludwig Chrysostomus. Pedoman Praktis Untuk Pelayanan Pastoral. BPK Gunung Mulia, 2010.

Brill, J. Wesley. Dasar Yang Teguh. Bandung: Kalam Hidup, 2015.

Budiman, Sabda, and Susanto Susanto. "Strategi Pelayanan Pastoral di Masa Pandemi Covid-19 Menuju Pertumbuhan Gereja yang Sehat.” PNEUMATIKOS: Jurnal Teologi Kependetaan 11, no. 2 (April 5, 2021): 95-104.

Comiskey, Joel. Ledakan Kelompok Sel. Jakarta: Metanoia, 1998.

D.A. Carson et al. Tafsiran Alkitab Abad Ke-21 Jilid 3: Matius-Wahyu. Jakarta: Yayasan Komunikasi Bina Kasih, 2017.

Deden, Rahmat H., and Zaenudin A. Naufel. Teori Dan Aplikasi Psikologi Kepribadian Dalam Konseling. Bogor: Ghalia Indonesia, 2011.

\footnotetext{
${ }^{37}$ Albet Saragih and Johanes Waldes Hasugian, "Model Asuhan Keluarga Kristen Di Masa Pandemi Covid-19," JURNAL TERUNA BHAKTI 3, no. 1 (September 2020): 6.

${ }^{38}$ Ibid., 7.
} 
Fauziyah, Mayang R.N., N.A. Damayani, and A.S. Rohman. "Perilaku Knowledge Sharing Multi Bahasa Pada Komunitas Fakta Bahasa." Jurnal Kajian Informasi dan Perpustakaan 2, no. 2 (December 2014): 87-102.

Halawa, Junius. "Pastoral Konseling Psikologi Alkitabiah Bagi Perempuan Yang Telah Melakukan Hubungan Seks Sebelum Menikah.” Missio Ecclesiae 7, no. 2 (October 2018): 287-317.

Haryani, Titik. "Pentingnya Pelayanan 'Inner Healing' dalam Gereja.” Jurnal Antusias 5, no. 1 (June 2017): 115-130.

Henry, Matthew. Tafsiran Matthew Henry: Matius. Surabaya: Momentum, 2007.

Hosea, Amos. "FENOMENA KELOMPOK SEL (CELL GROUP) DALAM GEREJA LOKAL.” Diegesis : Jurnal Teologi 4, no. 1 (September 2019): 1-11.

Hudson, Neil. Imagine Church: Gereja Idaman, Gereja Pemuridan. Jawa Timur: Literatur Perkantas, 2017.

Intarti, Esther Rela. "Peranan Firman Allah Dalam Pelayanan Konseling Pastoral Yang Holistik." Regula Fidei 3, no. 2 (2018): 552-537.

Kadir, Abdul. "Konsep Pembelajaran Konseptual Di Sekolah.” Dinamika Ilmu 13, no. 1 (June 2013).

Kneller, G.F. Educational Anthropology: An Introduction. New York: John Wiley and Scons, 1965.

Krisetya, Mesach. Bela Rasa Yang Dibagirasakan. Jakarta: Duta Ministri, 2015.

Mimery, Nehemia. Rahasia Tentang Penggembalaan. Jakarta: Mimery Press, n.d.

Moleong, Lexy J. Metodologi Penelitian Kualitatif. Bandung: Remaja Rosdakarya, 2018.

Pattinama, Yenny Anita. "Pastoral Konseling Menurut Yehezkiel 34:16 Sebagai Upaya Pemulihan Mental.” Jurnal Scipta Teologi dan Pelaksanaan Kontekstual 3, no. 2 (2018): 172-183.

Pfeiffer, Charles F., and Everett F. Harrison, eds. Tafsiran Alkitab Wycliffe Volume 3. Malang: Gandum Mas, n.d.

Purba, Asmat. "Pemuridan Sebagai Tugas Dosen Pendidikan Agama Kristen Di Perguruan Tinggi." TEDC 8, no. 1 (January 2014): 68-73.

Ranto. "Pendekatan Pastoral Yesus Dalam Yohanes 21:15-19 Dan Aplikasinya Dalam Pelayanan Pastoral Pemulihan.” Rhema: Jurnal Teologi Biblika dan Praktik 4, no. 2 (2018): 87-98.

Saragih, Albet, and Johanes Waldes Hasugian. "Model Asuhan Keluarga Kristen Di Masa Pandemi Covid-19.” JURNAL TERUNA BHAKTI 3, no. 1 (September 2020): 1-11.

Scoot, Morton. Pemuridan Untuk Semua Orang. Surakarta: Literatur Perkantas, 2011. Selvianti. "Menerapkan Prinsip Pelayanan Konseling Berdasarkan Injil Yohanes." Jurnal Teologi dan Pendidikan Kristen Kontekstual 1, no. 2 (December 2018): 253-266. 
Sianipar, Florentina. "Strategi Pelayanan Pastoral Konseling Sebagai Upaya

Meningkatkan Antusiasme Jemaat Dalam Beribadah.” Missio Ecclesiae 8, no. 2

(October 2019): 137-154.

Simamora, May Rauli, and Johanes Waldes Hasugian. "Penanaman Nilai-Nilai Kristiani Bagi Ketahanan Keluarga Di Era Disrupsi." REGULA FIDEI: Jurnal Pendidikan Agama Kristen 5, no. 1 (June 2020): 13-24.

Soekanto, Soerjono. Sosiologi: Suatu Pengantar. Jakarta: Rajawali Press, 1983.

Sukamnto. Rahasia Keberhasilan Gereja Di Korea. Yogyakarta: ANDI, 2006.

Susabda, Yakub B. Pastoral Konseling Jilid 1. Malang: Gandum Mas, 2003.

Susanto. Bahan Kuliah Konseling Pastoral, n.d.

Tanto, Obaja. 12 Prinsip Kelompok Sel. Solo: Departemen Media, 2000.

Wagner, Peter. Your Church Can Grow. Venture: Regal Books, 1984. 